\title{
Tungstate Based Ceramics Obtained By Spark Plasma Sintering Method - Possible Material for Consolidation of Radioactive Wastes' Components
}

\section{E. A. Potanina 1,2, D. A. Mikhailov², M. S. Boldin², A. V. Nokhrin², N. V. Sakharov², O. A. Belkin², E. A. Lantsev², and M. G. Tokarev \\ 1Department of chemistry, Lobachevsky State University of Nizhny Novgorod, 23, Gagarin Ave, BLDG 2, 603950 Nizhny Novgorod, Russia \\ ${ }^{2}$ Physics and Technology Research Institute, Lobachevsky State University of Nizhny Novgorod, 23, Gagarin Ave, BLDG 3, 603950 Nizhny Novgorod, Russia}

\section{Abstract}

The Spark Plasma Sintering method was used to produce high-density ceramics from tungstates $\mathrm{SrWO}_{4}$ and $\mathrm{NaNd}\left(\mathrm{WO}_{4}\right)_{2}$ with scheelite structure. These compounds are

Corresponding Author:

E. A. Potanina

ekaterina.potanina@list.ru

Received: 21 December 2017

Accepted: 15 April 2018

Published: 6 May 2018

Publishing services provided by Knowledge $\mathrm{E}$

(c) E. A. Potanina et al. This article is distributed under the terms of the Creative Commons

Attribution License, which permits unrestricted use and redistribution provided that the original author and source are credited.

Selection and Peer-review under the responsibility of the MIE-2017 Conference Committee.

\section{G OPEN ACCESS} proposed as possible matrices for the consolidation of radwaste components. Powder samples were obtained by coprecipitation method and studied by X-ray diffraction analysis (XRD) and scanning electron microscopy (SEM). After sintering, the samples retained their phase identity (scheelite structure). The total duration of sintering was $\sim 13-15$ min, the relative density was reached $\sim 92,99 \%$.

Keywords: Tungstates, RW, Spark Plasma Sintering, high density, microstructure

\section{INTRODUCTION}

In the context of continuously developing sciences and high technology, the need for new functional materials with predetermined properties, including those contributing to the task of safe handling of radioactive waste (RW) and spent nuclear fuel (SNF), is constantly increasing.

Mineral-like materials are promising for the consolidation of RW elements [1-4]. They are characterized by a large isomorphism in the cationic and/or anionic parts of the crystal structure, and therefore it becomes possible to obtain solid solutions of various compositions and complexities, to plan and control their properties.

In the frame of the problem of radioactive waste management, specialists pay attention to compounds with structures of natural minerals: monazite [5-7], kosnarite [8-11], 
langbeinite [11, 13], whitlockite [14], etc. Crystalline materials, and ceramics with the structure of the mineral scheelite are less studied.

It is known that isostructural scheelite-like compounds and solid solutions can contain in their composition many elements whose isotopes are present in the waste of radiochemical technologies [15-16]. Among them, solid solutions of tungstates and molybdates of cerium [17], thorium, uranium, plutonium [18-20]. Moreover, tungstates and isostructural molybdates with scheelite structure can be formed in precipitation processes in alkali chloride melts and possess high chemical stability in relation to them [21-23]. This is especially important in the development of methods for consolidation of RW by pyro-chemical technology for regenerating MOX fuel, since their stability is also maintained with respect to chloride melts of $\mathrm{LiCl}-\mathrm{KCl}[24]$.

The task of this work was to study compounds with scheelite structure (natural analogue of $\left(\mathrm{CWO}_{4}\right)$ in order to evaluate the possibility of their using as matrices for immobilization of HLW in radiochemical technologies.

Scheelite structure has a frame structure, tetragonal syngony, s.g. $14_{1} / a$. The Ca atoms are surrounded by eight 0 atoms by the dodecahedron motif, and the $\mathrm{W}$ atoms by the four 0 atoms over the tetrahedron. The eight vertices of $\mathrm{CaO}_{8}$ are interconnected by ribs, and each polyhedron is conjugated to four neighboring $\mathrm{CaO}_{8}$ [25].

For tungstates with a scheelite structure iso- and heterovalent isomorphism is possible. In calcium tungstate $\mathrm{CaWO}_{4}$, the $\mathrm{Ca}^{2+}$ cation can be partially or completely replaced by $\mathrm{Sr}^{2+}, \mathrm{Ba}^{2+}, \mathrm{Cu}^{2+}, \mathrm{Mn}^{2+}, \mathrm{Cd}^{2+}, \mathrm{Pb}^{2+}, \mathrm{Cr}^{3+}, \mathrm{Fe}^{3+}, \mathrm{REE} \mathrm{Nb}^{5+}, \mathrm{Ta}^{5+}$, and the $\mathrm{W}^{6+}$ cation can be also partially or completely replaced by $\mathrm{Ge}^{4+}, \mathrm{V}^{5+}, \mathrm{Mo}^{6+}, \mathrm{I}^{7+}, \operatorname{Re}^{7+}[16,26]$.

Compounds with a scheelite structure are investigated as matrices for the consolidation of alkaline-earth elements, including from chloride melts used in the reprocessing of irradiated nuclear fuel $[23,27]$. Neodymium in the composition of compounds is both as a product of nuclear fission, and analogue of americium.

Usually, in the first stage, crystalline compounds with RW components are obtained in the form of powders. This form of waste consolidation is not sufficiently reliable, so it is proposed to immobilize powder samples into ceramics. This approach allows make further storage of radioactive waste more safe.

Among the various methods for powders sintering into ceramics, in recent years the interest in the Spark Plasma Sintering (high-speed electropulse sintering) method has been an increasing as promising for obtaining ceramic samples with a high relative density, including for possible applications in nuclear technologies [28, 29]. Its advantage lies in the possibility of changing the sintering parameters (the gaseous environment, the volume of the applied load, the temperature and the duration of the 
isothermal holding) in wide ranges and the possibility of adjusting these parameters during the sintering process.

The SPS method can be used to produce materials based on metals, oxides, and composites. In $[7,30,31]$ data on the production of dense ceramics of complex phosphate compounds of a salt and oxide character are presented.

In this work compounds with a scheelite structure, containing neodymium and alkaline-earth elements, were obtained, in the first stage in the form of powders and in the second stage in ceramic form, characterize the powders and ceramics obtained, and some of its properties were studied.

\section{MATERIALS AND METHODS}

At the first stage of the work, powder samples of $\mathrm{SrWO}_{4}$ and $\mathrm{NaNd}\left(\mathrm{WO}_{4}\right)_{2}$ compounds with a scheelite structure were synthesized.

At the second stage of the work, ceramics by the SPS method were obtained, as a more acceptable form of storage; characterization of the resulting powders and ceramics was carried out.

\subsection{Synthesis}

Powders were synthesized by coprecipitation from aqueous solutions. Ammonium tungstate $\left(\mathrm{NH}_{4}\right)_{4} \mathrm{~W}_{5} \mathrm{O}_{17} \cdot 2.5 \mathrm{H}_{2} \mathrm{O}$ was dissolved in distilled water at $\mathrm{T}=80{ }^{\circ} \mathrm{C}$ with constant stirring. After complete dissolution of ammonium tungstate, nitrates of strontium or sodium and neodymium were added. In this case, instant precipitation of the precipitate in the case of strontium and gelling for the compound with sodium and neodymium were observed. The suspensions were stirred for 30 minutes with a magnetic stirrer, then dried at $\mathrm{T}=90^{\circ} \mathrm{C}(12 \mathrm{~h}), 120^{\circ} \mathrm{C}(2 \mathrm{~h})$, dispersed in an agate mortar for 10 minutes and subjected to high temperature treatment sequentially at $T=800$, $900,1000,1100{ }^{\circ} \mathrm{C}$ for 10 hours with intermediate dispersion at each stage. After each isothermal holding the phase affinity of the powder samples was characterized by the XRD method.

The ceramics were obtained by the Spark Plasma Sintering (SPS) method. The heating rate during the sintering process was $\mathrm{V}_{H}=30^{\circ} \mathrm{C} / \mathrm{min}$. Sintering was carried out in a vacuum (6 Pa) at uniaxial stress of $75 \mathrm{MPa}$. The duration of the process did not exceed $15 \mathrm{~min}$. The temperature was measured by a pyrometer focused on the surface of the graphite mold. 


\subsection{Equipment}

The phase composition of the powders was controlled by the XRD method on a Shimadzu LabX XRD-600o powder diffractometer, X-ray patterns were made in the range of $10-50^{\circ}$ at the scanning speed of $2 \%$ min and were indicated using the PDF ICDD database.

The microstructure of the powders and sintered ceramics was investigated by a Jeol JSM-6490 scanning electron microscope with an INCA 350 energy dispersive microanalyzer was used.

The ceramics were sintered on a Dr.Sinter Model-625 produced by SPS Syntex Inc. Ltd. (Japan).

The density of the sintered samples $\left(\rho_{\exp }\right)$ was measured by hydrostatic weighing in distilled water by using a Sartorius CPA weigher. The relative density of the samples ( $\rho$ ) was calculated by dividing $\rho_{\text {exp }}$ by the theoretical density $\rho_{t h}$, calculated from the results of $\mathrm{X}$-ray phase analysis.

\section{RESULTS AND DISCUSSION}

\subsection{Characterization of powders}

The obtained substances were polycrystalline powders of white (Sr-containing) or dark-lilac (Nd-containing) powders.

According to the X-ray diffraction data, $\mathrm{SrWO}_{4}$ and $\mathrm{NaNd}\left(\mathrm{WO}_{4}\right)_{2}$ compounds crystallize in the scheelite structure, s.gr. I4/a (Fig. 1).

The crystallographic parameters of the unit cells and the theoretical densities of the compounds had the following values: $\mathrm{SrWO}_{4}$ ) $a=b=5.4293 \AA, c=11.9781 \AA, \alpha=\beta=$ $\left.\gamma=90^{\circ}, \rho_{t h}=6.3086 \mathrm{~g} / \mathrm{cm}^{3} ; \operatorname{NaNd}\left(W_{O_{4}}\right)_{2}\right) a=b=5.2954 \AA, c=11.4930 \AA, \alpha=\beta=\gamma=$ $90^{\circ}, \rho_{t h}=6.8290 \mathrm{~g} / \mathrm{cm}^{3}$.

Scanning electron microscopy was used to study the microstructure of powder samples. The results of SEM are shown on Figure 2

Powders in their structure have a faceted shape. The particle size distribution of the powders is not uniform in size - in the compositions there are both large particles, whose average size reaches $10 \mu \mathrm{m}$, and ultrafine particles with a size of less than $1 \mu \mathrm{m}$. A possible reason for the formation of ultrafine particles is the operation of grinding the powders after their reducing annealing at a temperature of $800{ }^{\circ} \mathrm{C}$. 


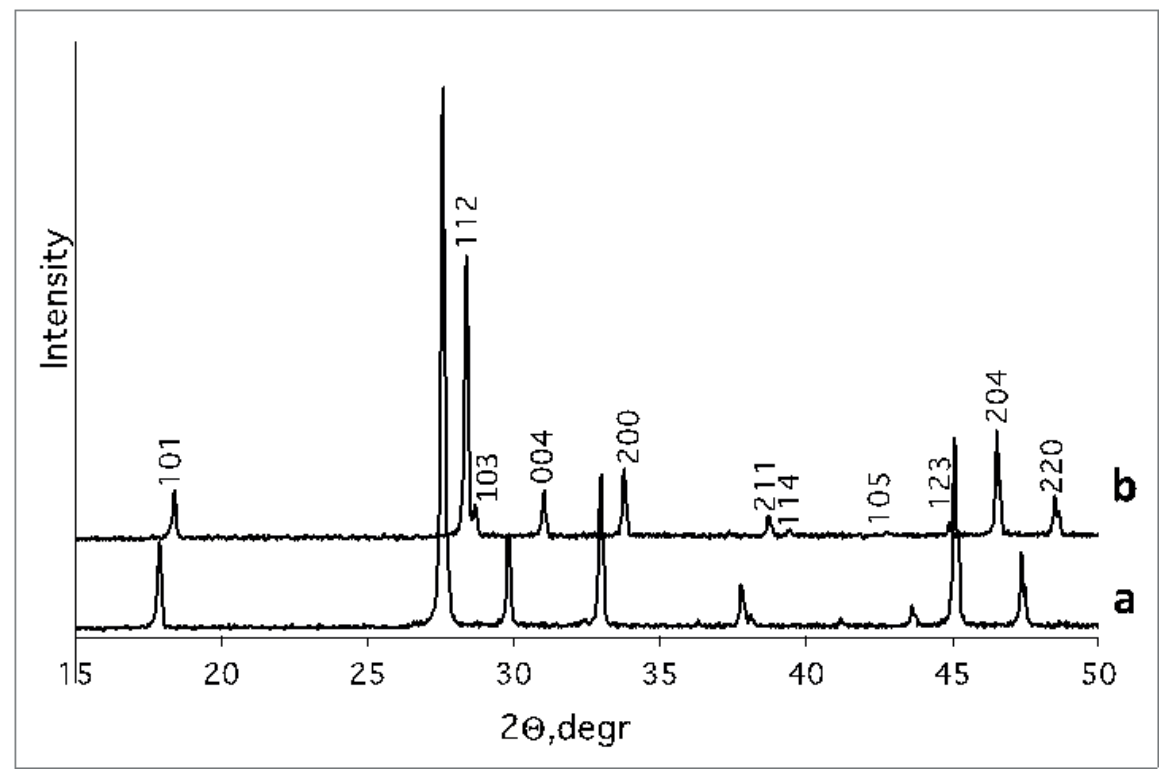

Figure 1: XRD data. Compounds (a) $\mathrm{SrWO}_{4}$, (b) $\mathrm{NaNd}\left(\mathrm{WO}_{4}\right)_{2} . \mathrm{T}=800^{\circ} \mathrm{C}$.
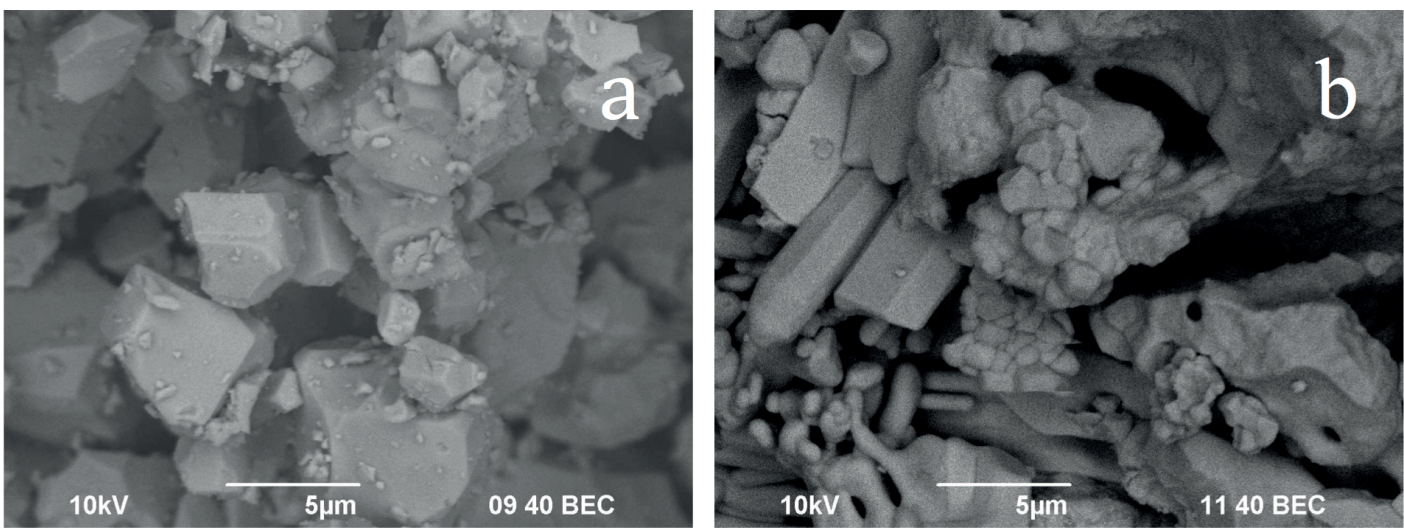

Figure 2: Photographs showing the microstructure of (a) $\mathrm{SrWO}_{4}$ and (b) $\mathrm{NaNd}\left(\mathrm{WO}_{4}\right)_{2}$ powders.

\subsection{Characterization of ceramics}

The sintering patterns of the ceramic samples are shown in Figure 3.

It can be seen that the samples of tungstates are sintered at sufficiently low temperatures, the sintering was completed at 770 and $830{ }^{\circ} \mathrm{C}$, the isothermal holding period was absent, the relative densities achieved were 92 and 99 for $\mathrm{SrWO}_{4}$ and $\mathrm{NaNd}\left(\mathrm{WO}_{4}\right)_{2}$, respectively.

The phase composition of the ceramics was compared with the phase composition of the powders - the XRD data indicate that sintering does not lead to a change in the phase composition of the materials, which indicates their enhanced thermal stability. Figure 4 shows the $\mathrm{X}$-ray diffraction patterns of the resulting ceramics 

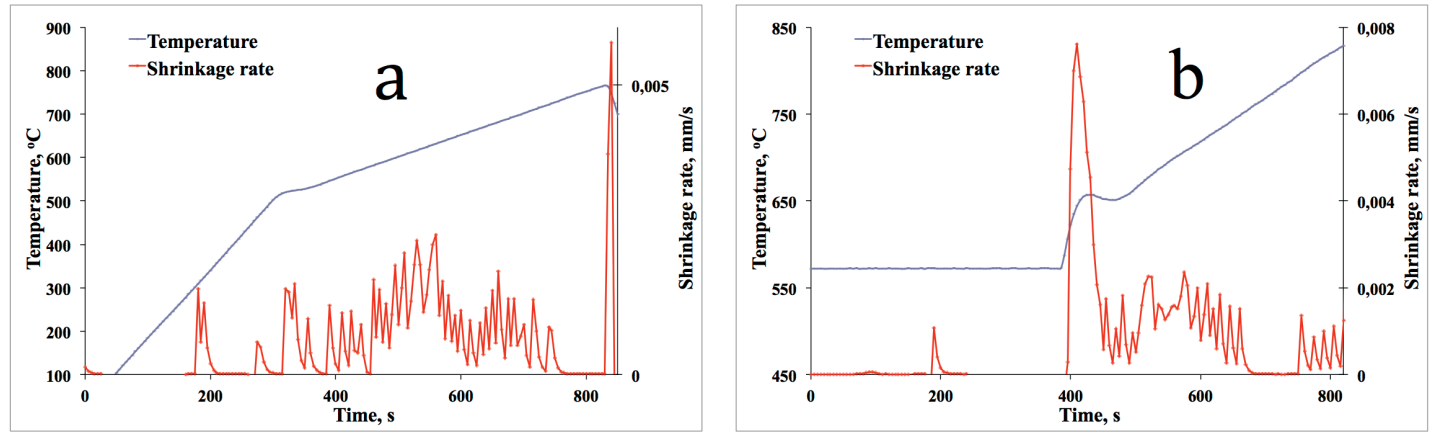

Figure 3: Dependence of the shrinkage rate $(\mathrm{S})$ and temperature $(\mathrm{T})$ on the time $(\mathrm{t})$ of $\mathrm{SrWO}_{4}(\mathrm{a})$ and $\mathrm{NaNd}\left(\mathrm{WO}_{4}\right)_{2}$ (b).

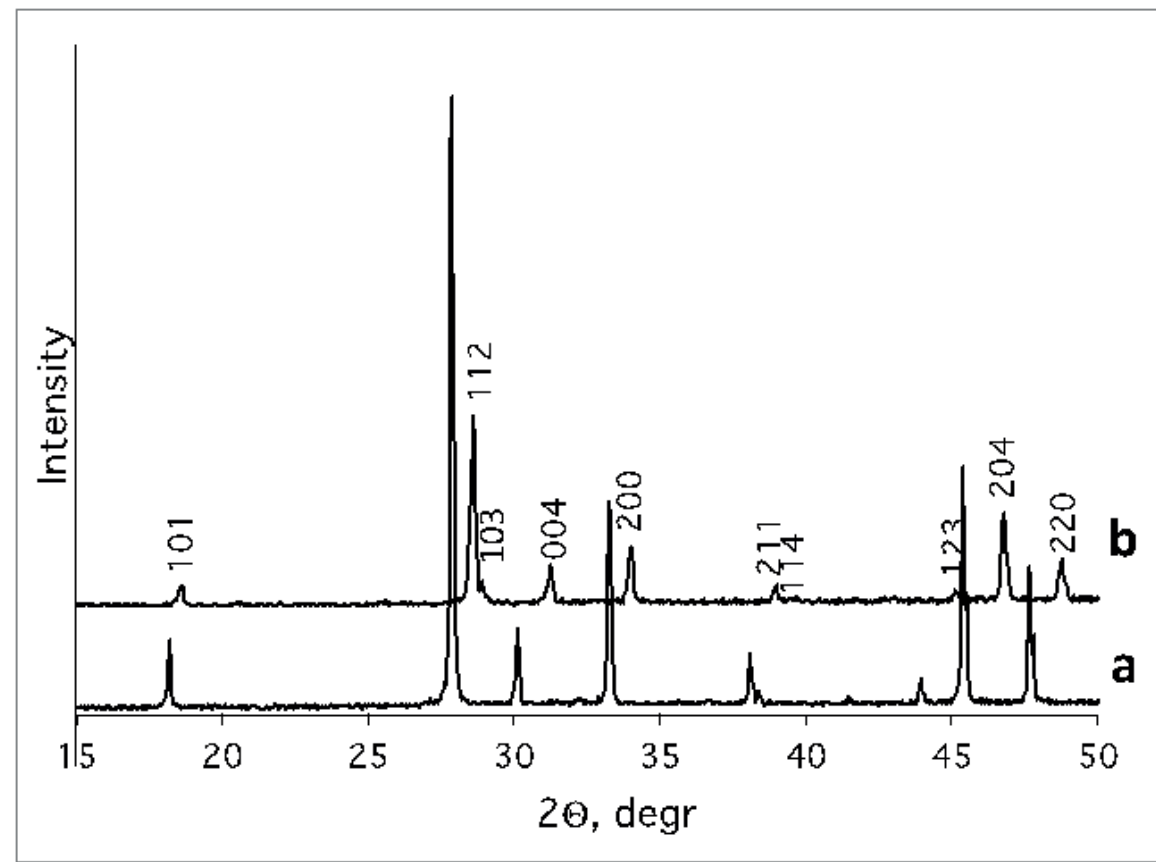

Figure 4: XRD data. Compounds (a) $\mathrm{SrWO}_{4}$, (b) $\mathrm{NaNd}\left(\mathrm{WO}_{4}\right)_{2}$ after sintering.

Microphotographs of the structure of sintered ceramic samples are shown in Figure 5 .

The results of electron microscopic studies indicate that ceramics have a highdensity fine-grained structure. Moreover, the microstructure images of the ceramics (Figure 6) show that formation of a finer-grained structure in the samples of ceramics $\mathrm{NaNd}\left(\mathrm{WO}_{4}\right)_{2}$. As can be seen from Figure 6, the average grain size in a ceramic based on $\mathrm{SrWO}_{4}$ is 5-10 $\mu \mathrm{m}$, and the average grain size in $\mathrm{NaNd}\left(\mathrm{WO}_{4}\right)_{2}$ ceramics is $1-2 \mu \mathrm{m}$.

We note that, despite the short sintering time, the absence of the isothermal holding stage and the high heating rate, the relative density of the obtained ceramics is high and it was 92 and $99 \%$ of the theoretical density of these compounds. 

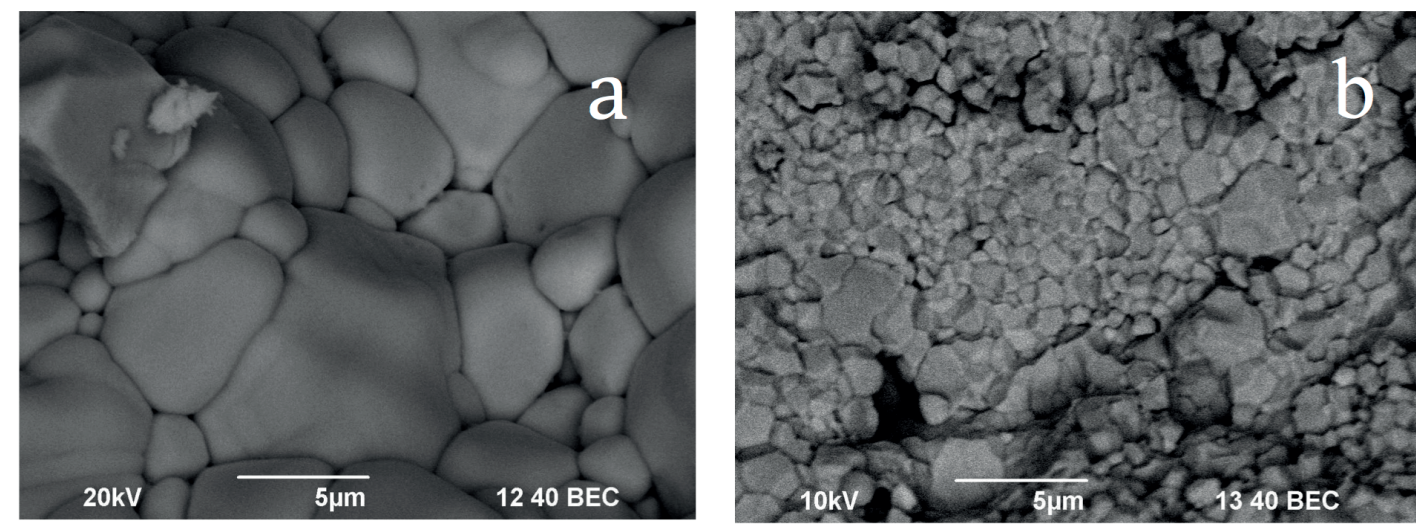

Figure 5: Photographs showing the microstructure of (a) $\mathrm{SrWO}_{4}$, (b) $\mathrm{NaNd}\left(\mathrm{WO}_{4}\right)_{2}$ in ceramics. Scanning electron microscopy of fractures.

\section{CONCLUSIONS}

1. The tungstates with compositions $\mathrm{SrWO}_{4}, \mathrm{NaNd}\left(\mathrm{WO}_{4}\right)_{2}$ were obtained by the coprecipitation method.

2. The SPS method was used for obtaining almost non-porous ceramics.

3. For the sintering processes the following optimum conditions were achieved: $T_{\sin }$ $=770-830^{\circ} \mathrm{C}, \mathrm{P}=75 \mathrm{MPa}, \mathrm{t}_{\text {sin }}$ did not exceed $15 \mathrm{~min}, \rho_{\text {rel }}=92,99 \%$

4. Microphotographs of powders and ceramics show that the particle size in the initial powder and the ceramics obtained from it practically did not change, the separation of the agglomerate grains to larger particles did not occur

5. The SPS method can be recommended for obtaining dense ceramics based on complex salt compositions, as fast and allowing to save the microstructure of the initial objects.

The work was supported by Russian Science Foundation (project №16-13-10464 "Advanced ceramic like mineral materials with improved and adjustable service characteristics: design, synthesis, study").

\section{References}

[1] G.J. McCarthy, M.T. Davidson, Bull. Am. Ceram. Soc. 54 (1975) 782.

[2] Lutze, R.WC. Ewing, North-Holland Publishers, Amsterdam (1988) 778.

[3] B.E. Burakov, M.I. Ojovan, W.E. Lee, Imperial College Press, Materials for Engineering, (2010) 1. 
[4] C.M. Jantzen, W.E. Lee, M.I. Ojovan, In Book "Radioactive Waste Management and Contaminated Site Clean-Up. Processes, Technologies and International Experience". Ed. by: W.E. Lee, M.I. Ojovan, C.M. Jantzen, Oxford, Cambridge, Philadelphia, New Delhi. Woodhead Published Limited, 852 p., Chapter 6, 2013, p. 171.

[5] N. Clavier, R. Podor, N. Dacheux, Journal of European Ceramic Society 31 (6) (2011) 941.

[6] N. Dacheux, N. Clavier, R. Podor, Am. Mineral 98 (2013) 833.

[7] E. Potanina, L. Golovkina, A. Orlova, A. Nokhrin, M. Boldin, N. Sakharov, J. Nuclear Materials 473 (2016) 93.

[8] H.T. Hawkins, D.R. Spearing, D.K. Veirs, J.A. Danis, D.M. Smith, C.D. Tait, W.H. Runde, Chemistry of Materials 11 (1999) 2851.

[9] A.I. Orlova, Radiochemistry 44 (5) (2002) 423.

[10] Yu.F. Volkov, S.V. Tomlin, A.I. Orlova, A.A. Lizin, V.I. Spirjakov, A.N. Lukinikh, Radiochemistry 46 (4) (2003) 319.

[11] A.I. Orlova, In Book: Structural Chemistry of Inorganic Actinide Compounds. Chapter 8. By ed. S.V. Krivovichev, P.C. Burns, I.G. Tananaev. ELSEVIER. Amsterdam, (2007) 315 .

[12] D.J. Gregg, I. Karatchevtseva, G.J. Thorogood, J. Davis, B. Bell, M. Jackson, P. Dayal, M. Ionescu, G. Triani, K. Short, G.R. Lumpkin, E.R. Vance, J. Nucl. Mater. 446 (2014) 224.

[13] A.I. Orlova, A.K. Koryttseva, E.E. Loginova, Radiochemistry, 53 (1) (2011) 51.

[14] A.I. Orlova, N. Malanina, V.N. Chuvildeev, M.S. Boldin, N.V. Sakharov, A.V. Nokhrin, Radiochemistry 56 (4) (2014) 322.

[15] D. Errandonea, F.J. Manjón, Prog. Mater. Sci. 53 (2008) 711.

[16] B. Macey, Thesis. Master of geological science. Blacksburg: Virginia Polytechnic Institute and State University (1995) 69 p.

[17] A.M. Golub, V.N. Maxin, Sov. J. Inorg. Chem. 22 (1) (1977) 115.

[18] A. Tabuteau, M. Pages, W. Freundlich, Mat. Res. Bull 7 (7) (1972) 631.

[19] M.R. Lee, P. Mahe, C. r. Acad. Sci. Paris 279 (26) (1974) 1137.

[20] M.R. Lee, P. Mahe, C. r. Acad. Sci. Paris 282 (3) (1976) 161.

[21] A.I. Kryukova, G.N. Kazantsev, R.A. Bragina, Sov. Radiochemistry 29 (5) (1987) 599.

[22] A. Tabuteau, M. Pages, J. Inorg. Nucl. Chem. 42 (3) (1988) 401.

[23] A.I. Kryukova, I.A. Korshunov, Sov. Trudi po chimii i chimicheskoi technologii 2 (1965) 95. 
[24] M.G. Tokarev, E.A. Potanina, A.I. Orlova, M. Yu. Kalenova, Book of Abstracts of VI all-Russian youth school on radiochemistry and nuclear technology, Ozyorsk, 2014, p. 48.

[25] V. K. Trunov, V. A. Efremov, Yu. A. Velikodniy, Crystal chemistry and properties of double molybdates and tungstates - Leningrad: Publishing House "Nauka", Leningrad branch, (1986) pp. 173

[26] V. A. Morozov, A. V. Mironov, B. I. Lazoryak, J. Solid State Chem., 179 (4) (2006) 1183.

[27] D. Errandonea, F. J. Manjón, Prog. Mater. Sci. 53 (2008) 711.

[28] H.R. Williams, H. Ning, M.J. Reece et al., J. Nucl. Mat. 433 (1-3) (2013) 116.

[29] R. C. O’Brien, R.M. Ambrosi, N. P. Bannister, S. D. Howe, H. V. Atkinson, J. Nucl. Mat. 393 (2009) 108.

[30] A. I. Orlova, A. K. Koryttseva, A. E. Kanunov et al., Inorg. Mat. 48 (3) (2012) 98.

[31] A.I. Orlova, A.N. Troshin, D.A. Mikhailov et al., Radiochemistry 56 (1) (2014) 87. 